JOURNAL OF NEUROBIOLOGY, VOL. 2 , NO. 2, PP. 153-168

\title{
EFFECT OF THE CONVULSANT METHIONINE SULFOXIMINE ON THE IN VIVO UPTAKE AND METABOLISM OF D-METHIONINE IN RAT BRAIN*
}

\author{
NORA E. GHITTONI $\dagger$ and OTTO Z. SELLINGER $\ddagger$
}

Mental Health Research Institute, University of Michigan Medical Center, Ann Arbor, Michigan 48104

\begin{abstract}
SUMMARY
D-methionine was administered intraperitoneally to rats in tracer (2$2.5 \mu$ moles $/ \mathrm{kg})$ and large doses $(4.7 \mathrm{mmoles} / \mathrm{kg})$ and the brain levels of total $(\mathrm{D}+\mathrm{L})$ methionine, as well as of cysteine (+ cystine) and glutathione were determined. The effect of co-administering the convulsant agent, L-methionine-DL-sulfoximine (MSO) was also examined. The administration of tracer doses of $\mathrm{C}^{12}$-D-methionine resulted in a doubling of total brain methionine within 4 hours post-injection, but only in a moderate increase of the levels of cysteine. When $\mathrm{C}^{14}-\mathrm{D}$-methionine was used as tracer, the peak increase of the isotopic methionine pool and a peak accumulation of $0.35 \%$ of the injected radioactivity were noted in the brain within 1.5 hours. When 4.7 mmoles $/ \mathrm{kg}$ of D-methionine were administered, total brain methionine and cysteine increased by 4 and 3-fold respectively, the former peaking at $1.5 \mathrm{hr}$ and the latter at 2.5 hr post-injection. The administration of MSO retarded the attainment of these peaks. It could also be shown that while about $65 \%$ of the total brain methionine existed as the D-isomer $1.5 \mathrm{hr}$ after its administration, only $46 \%$ was still present as the D-isomer $0.5 \mathrm{hr}$ later. When MSO was administered simultaneously with D-methionine, the corresponding percentage values stood at $70 \%$ at 1.5 and at $2 \mathrm{hr}$. The results, therefore, suggest that even though D-methionine reaches the brain largely unchanged, its uptake and its conversion to the natural L-isomer may be inhibited by MSO under certain conditions and hence its conversion to cysteine retarded.
\end{abstract}

\section{INTRODUCTION}

The disposition of in vivo administered D-amino acids by brain tissue has been investigated by Lajtha and his associates (Lajtha and Toth,

* Supported by grants No. NB-06294 and MH-07417 from the United States Public Health Service and by a grant from the Epilepsy Foundation of America.

$\dagger$ Postdoctoral trainee, 1967-1969. Present address: Faculdad de Farmacia y Bioquimica, Universidad de Buenos Aires, Buenos Aires, Argentina.

$\ddagger$ To whom requests for reprints should be addressed.

153

(C) 1971 by John Wiley \& Sons, Inc. 
1962, 1963; Lajtha, 1968) who worked principally with the D-isomers of leucine, lysine and phenylalanine, and by Chirigos et al. (1960) and Guroff and Udenfriend (1962) who examined the uptake of D-tyrosine and Dtryptophan. In all cases, little if any racemization of the administered Damino acids to the natural L-isomers was noted. More recently Shah et al. (1968) reported that L-methionine markedly reduced the in vivo uptake by the brain of dihydroxyphenylalanine while D-methionine had no such effect. In vitro, Nakamura (1963) noted that L- and D-methionine interfere equally effectively with the uptake of L-histidine by brain slices.

Cerebral cell-free preparations have also been examined for their ability to react with D-amino acids (Burch et al., 1956; Neims et al., 1966; Goldstein, 1966) and the presence of $\mathrm{D}$-amino acid oxidase has been reported in the brain of several species. More recently, de Marchi and Johnston (1969) ascribed to D-amino acid oxidase the cerebellar and spinal cord enzymatic activity which they found to react with glycine and with several other $\mathrm{D}$-amino acids.

Pursuing our long-standing interest in the mechanism of action of the convulsant methionine sulfoximine (Lamar and Sellinger, 1965; de Robertis et al., 1967; Sellinger et al., 1968; Ghittoni et al., 1970; Ghittoni and Sellinger, 1970) we recently tested the ability of several analogs and derivatives of methionine to protect rats against epileptic seizures induced by this drug and we noted that $D$-methionine was as effective as the L-isomer (Sellinger et al., 1968).

Subsequently, we described effects of L-methionine on the regional and intracellular disposition of $\left[{ }^{3} \mathrm{H}\right]-\mathrm{MSO}$ in rat brain (Ghittoni et al., 1970) and changes in the levels of cerebral methionine and cysteine elicited by the administration of MSO (Ghittoni and Sellinger, 1970). In the present report we describe results of experiments which demonstrate the ability of brain tissues to take up D-methionine, convert it to the L-isomer and form cysteine therefrom. A study of the effects of MSO on the cerebral disposition of D-methionine is also included.

\section{METHODS}

Materials. The following compounds were obtained as indicated: L-methionineDL-sulfoximine, D-methionine, and ninhydrin from Pierce Chemical Co., Rockford, Ill.; L-methionine from Nutritional Biochemicals Inc., Cleveland, Ohio; C $\mathbf{C}^{14}$-(methyllabeled) D-methionine (s.a.: $6.2 \mathrm{mCi} / \mathrm{mmole}$ ) from ICN Co., City of Industry, Calif; snake venom L-amino acid oxidase and hog kidney D-amino acid oxidase (3.6 units/mg and 4.5 units/mg, respectively) and beef liver catalase $(53,650$ units $/ \mathrm{mg}$ ) from Worthington Biochem. Co., Freehold, N. J.; CoA, acetyl phosphate and phosphotransacetylase (s.a.: 1,200 units $/ \mathrm{mg}$ ) from Boehringer Mannheim, New York, N. Y.; Dowex-AG2 × 10 (100-200 mesh), chloride form, from Bio-Rad Laboratories, Richmond, Calif; Dowex 50 W-X8 from Baker Chem. Co., Phillipsburg, N. J.; PPO and dimethyl POPOP from Packard Instruments, Downers Grove, Ill.; Biosolv-3 from Beckman Instruments Co., Palo Alto, Calif.; 5,5'-dithiobis (2 nitrobenzoic acid) from K \& K Laboratories, Plainview, N. Y.; 3-hydrazinoquinoline dihydrochloride from Eastman Organic Chem. Co., Rochester, N. Y.; dithiothreitol from Calbiochem., 
Los Angeles, Calif.; FAD from Sigma Co., St. Louis, Mo.; N-acetyl-D-methionine from Cyclo Chemical Co., Los Angeles, Calif.; and chloroplatinic acid from Matheson, Coleman, and Bell, East Rutherford, N. J.

Adult (200-250) male rats (Sprague-Dawley) were injected i.p. with a convulsant dose of MSO $(0.94 \mathrm{mmole} / \mathrm{kg})$ and, unless stated otherwise, a 5-fold molar excess of $\mathrm{D}$-methionine which included, when desired, a tracer dose of $\mathrm{C}^{14}$-D-methionine. Tracer $\mathrm{C}^{14}-\mathrm{D}$-methionine was also administered alone but when MSO was given simultaneously, the molar ratio of MSO to D-methionine was about 1:0.0025.

Preparation of the free amino acid pool. The animals were killed by decapitation and the rapidly excised brain was weighed and homogenized in $1 \%(\mathrm{w} / \mathrm{v})$ picric acid to make a $10 \%(\mathrm{w} / \mathrm{v})$ tissue suspension which was centrifuged at $12,000 \times \mathrm{g}$ for $10 \mathrm{~min}$. The sediment was washed once with $1 \%$ picric acid and the pooled supernatants were passed through a column $(1 \times 20 \mathrm{~cm})$ of Dowex AG2 $\times 10(100-200$ mesh) in the chloride form. The effluent contained the free amino acids. As reported previously (Lamar and Sellinger, 1965), MSO is quantitatively eluted from the Dowex column only after elution with $0.002 \mathrm{M} \mathrm{HCl}$.

Determination of cerebral methionine. Total methionine. The following procedure was adopted for the quantitative determination of total methionine in the brain. The sulfur-containing amino acids in the Dowex effuent (see above) were determined by the chloroplatinate procedure of Awwad and Adelstein (1966) which measures methionine, glutathione, and cysteine. The two latter compounds were therefore determined independently by the procedures of Jocelyn (1962) and Gaitonde (1967), respectively. After quantitative correction for the color contributions of glutathione and cysteine at $A_{500}$ in the procedure of Awwad and Adelstein (1966), methionine was calculated by applying the following formula:

$[$ Methionine $]=[$ Sulfur amino acids $]-\left[\frac{0.18}{0.75} \times(\right.$ glutathione $)+\frac{0.66}{0.75} \times$ (cysteine) $]$

where $0.18,0.66$, and 0.75 are the $A_{500}$ molar equivalent values for glutathione, cysteine, and methionine.

$L$-methionine. The L-isomer of methionine was assayed by condensing its keto analog, $\alpha$-keto- $\gamma$-methyl mercaptobutyrate (KMB) obtained after the action of L-amino acid oxidase, with 3-hydrazinoquinoline (Robins et al., 1956). The assay system contained $200 \mu$ moles of Tris buffer, $\mathrm{pH} \mathrm{7.8,100} \mathrm{Units} \mathrm{of} \mathrm{L-amino} \mathrm{acid} \mathrm{oxidase} \mathrm{and} 420$ units of catalase in addition to L-methionine and was incubated for $2 \mathrm{hr}$ at $30^{\circ} \mathrm{C}$. Aliquots of the acidified incubation mixture were assayed for keto acids as described by Robins et al. (1956). The procedure was standardized with $\alpha$-keto-glutarate.

$D$-methionine. The specific yeast $\mathrm{D}$-amino acid $\mathrm{N}$-acetyltransferase (Schmitt and Zenk, 1968) was used to $\mathrm{N}$-acetylate the $\mathrm{D}$-methionine present in the brain after its intraperitoneal administration. The assay system was as described by Schmitt and Zenk (1968), except that the concentration of acetyl phosphate (Lipmann and Tuttle, 1945) was $4 \mu \mathrm{moles} /$ tube. Incubations were at $30^{\circ}$ for $1 \mathrm{hr}$. To confirm the identity of the acetylated product, aliquots of the incubation mixtures were chromatographed on Whatman 3MM paper ascending in 1-butanol-gl. acetic acid-water $(20: 1: 4$ by volume) for comparison with authentic $\mathrm{N}$-acetyl-D-methionine $\left(\boldsymbol{R}_{\mathrm{f}}: 0.87\right)$.

Radioactive measurements. $\mathrm{C}^{14}$-D-methionine was checked for stereospecific purity as received from the supplier and also after treatment with $\mathrm{L}$ - and $\mathrm{D}$-amino acid oxidase. Radioactivity was determined in $15 \mathrm{ml}$ of scintillation fluid containing $4 \mathrm{~g}$ of 2,5-dyphenyloxazole (PPO) and $0.1 \mathrm{~g}$ of 1,4 bis- (4 methyl-5-phenyloxazolyl) benzene [dimethyl POPOP ] per liter of toluene or $1.9 \mathrm{~g}$ of PPO, $0.7 \mathrm{~g}$ of dimethyl POPOP and $60 \mathrm{~g}$ of naphthalene/liter of xylene, dioxane, and ethyl cellosolve $(1: 3: 1$ by volume). All radioactivity measurements were performed in a Unilux II liquid scintillation spectrometer (Nuclear Chicago, Des Plaines, Ill.) with an 80-85\% efficiency. Quenching corrections were applied using the channels ratio method. 


\section{RESULTS}

Effect of a tracer dose of D-methionine on total brain methionine. The i.p. injection of a tracer dose of $\mathrm{C}^{14}$-D-methionine (between 2 and $2.5 \mu \mathrm{moles} / \mathrm{kg}$ of body weight) resulted in about $4 \mathrm{hr}$ in an elevation of total brain methionine (Fig. 1) to twice the endogenous levels of Lmethionine $(0.059 \mu$ moles $/ \mathrm{g}$ of brain) (Ghittoni and Sellinger, 1970). The co-administration of MSO (Fig. 1, dashed line) appeared to stimulate this process during the first half hour presumably by rapidly mobilizing the entry of extracerebral stores of L-methionine into the brain (Ghittoni and Sellinger, 1970), or possibly, but less likely, by specifically facilitating the entry into the brain of the administered $\mathrm{D}$-isomer by virtue of a direct effect on the blood-brain barrier. It should be noted that when $\mathrm{C}^{{ }^{14}-\mathrm{D} \text { - }}$ methionine was administered alone (Fig. 1, solid line) a lowering of the levels of total methionine in the brain occurred during the first half hour; this may have been due to differences in the rates of flux of the administered D-methionine into, and of endogenous L-methionine out of, the brain with a consequent, temporary net decrement of the overall measurable methionine. Maximal radioactivity, expressed as $\mathrm{cpm} / \mu \mathrm{mole}$ of total methionine (Fig. 2) was reached within 30 min after $\mathrm{C}^{14}$-D-methionine alone and $1 \mathrm{hr}$ later when MSO was co-administered. Subsequently, the radioactivity present as methionine decreased to identical levels, irrespective of whether MSO was administered. Maximal cerebral as well

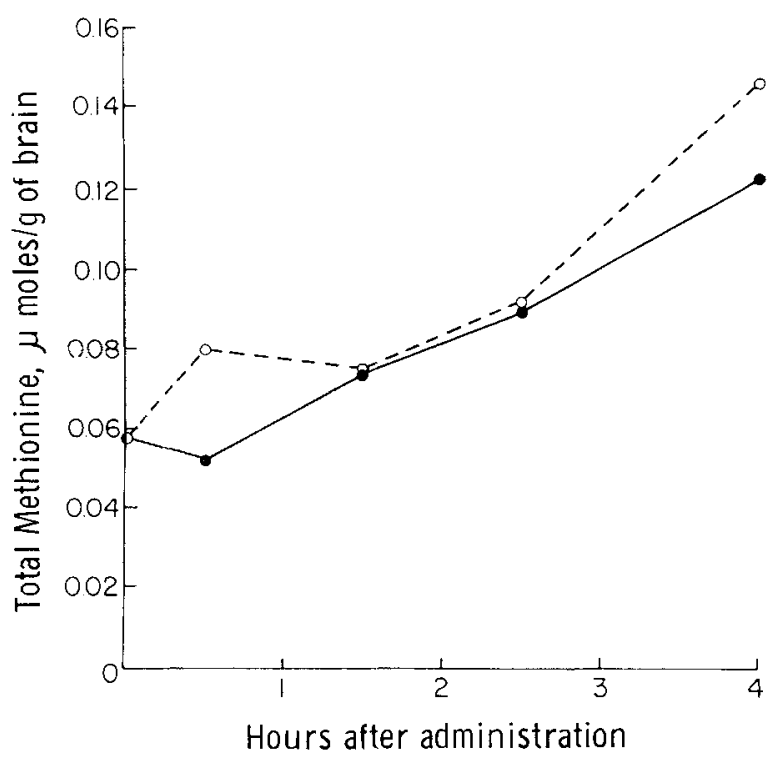

Fig. 1. Total brain methionine after the administration of a tracer dose of D-methionine \pm MSO. D-methionine $(2.0-2.5 \mu \mathrm{moles} / \mathrm{kg}$ of body weight) was administered intraperitoneally and total brain methionine was determined. The y-intercept represents the endogenous L-methionine concentration $(0.059 \mu$ moles $/ \mathrm{g})$. ( $\rightarrow$ D-methionine; (-.-) D-methionine + 0.94 mmoles $/ \mathrm{kg}$ of MSO. 


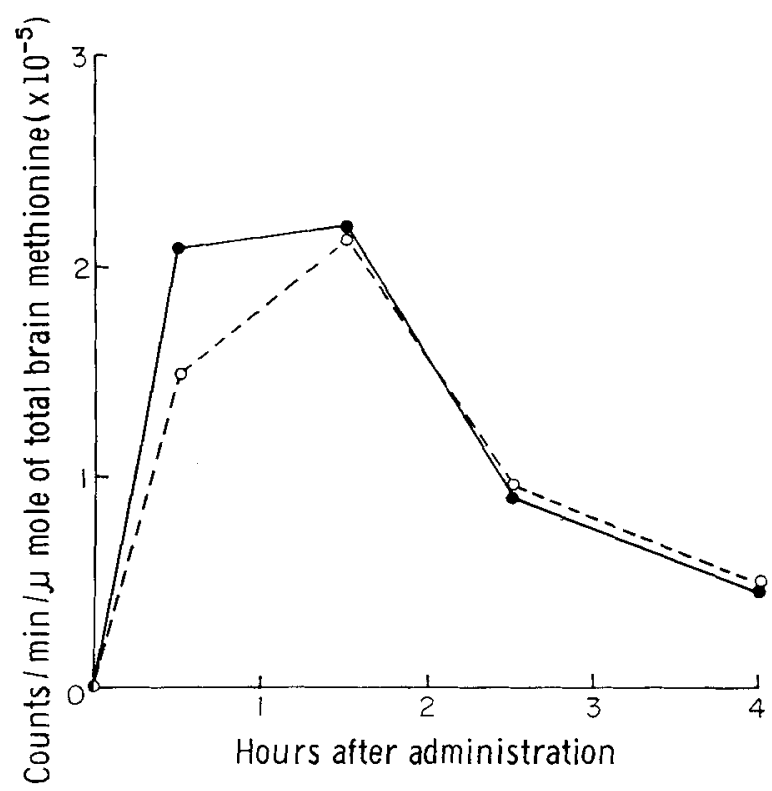

Fig. 2. The time course of cerebral labelling. $\mathrm{C}^{14}$-D-methionine (s.a.: $6.2 \mathrm{mCi} /-$ mmole, $4.5 \times 10^{6} \mathrm{cpm} / \mathrm{rat}$ ) was administered and the radioactivity of the acid-soluble materials determined, as indicated. (-) $\mathrm{C}^{14}-\mathrm{D}$-methionine; (---) $\mathrm{C}^{14-\mathrm{D}-m e t h i o n i n e}$ +0.94 mmoles $/ \mathrm{kg}$ of MSO.

as renal accumulation of the radioactivity, expressed as the per cent of the administered radioactive dose, also occurred between 30 and $90 \mathrm{~min}$. Its decay was faster in the brain than in the kidney, however, and was differentially influenced by MSO, so that more radioactivity appeared in the brain and less in the kidney when MSO was given than when it was omitted (Fig. 3, dashed lines).

The administration of tracer amounts of $\mathrm{C}^{14}-\mathrm{D}$-methionine also led to a slow, but significant trend toward higher than endogenous brain cysteine levels (Fig. 4); interestingly, this trend was initially opposed by the administration of MSO but later appeared to be stimulated by it (Fig. 4, dashed line).

Effect of a seizure-protective dose of D-methionine on total brain methionine. Figure 5 illustrates the changes of cerebral methionine after the injection of $4.7 \mathrm{mmoles} / \mathrm{kg}$ of $\mathrm{D}$-methionine (solid line) $+0.94 \mathrm{mmoles} / \mathrm{kg}$ of MSO (dashed line). It should be noted that since in Fig. 5 as in Fig. 1 the value at the y-axis intersect represents the endogenous L-methionine (Ghittoni and Sellinger, 1970), there was an apparent doubling of the endogenous methionine within $30 \mathrm{~min}$, presumably as a result of a massive and largely unimpeded surge of the injected $\mathrm{D}$-isomer into the brain. Peak accumulation occurred $1.5 \mathrm{hr}$ after $\mathrm{D}$-methionine alone and $0.5 \mathrm{hr}$ later when $\mathrm{MSO}$ was also given. Figure 5 also illustrates that although the administration of MSO had no apparent 


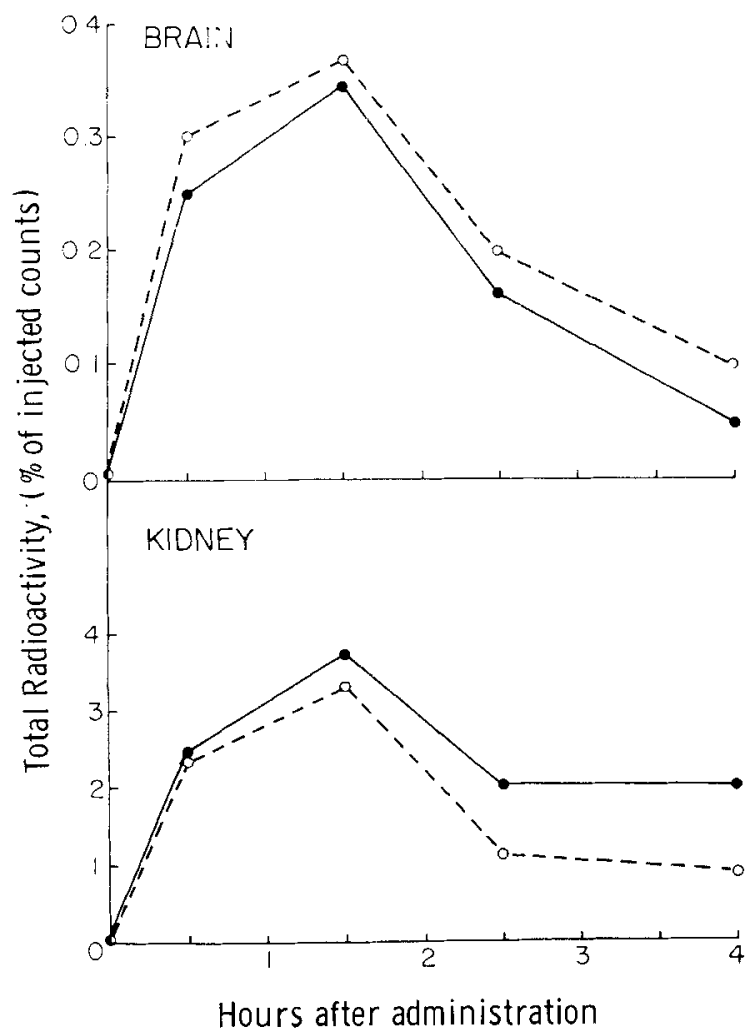

Fig. 3. The total radioactivity of brain and kidney after the administration of a tracer dose of D-methionine. For details of injection, see the caption for Fig. 1 . The total tissue radioactivity is expressed as $\%$ of the injected dose. $(-)$ D-methionine; (--) D-methionine $+0.94 \mathrm{mmoles} / \mathrm{kg}$ of MSO.

effect on the initial doubling of total cerebral methionine, it appeared to slow down the rate of its subsequent accumulation in the brain, possibly by causing a preferred efflux of the L-isomer or, more directly, by gradually impeding the otherwise free passage of the $\mathrm{D}$-isomer through the blood-brain barrier. The plots of Fig. 5 also show that, within the 4-hr experimental period, there was no net depletion of methionine in the brain as a result of the administration of MSO.

When a tracer dose of $\mathrm{C}^{14}$-D-methionine accompanied the 4.7 mmoles/ $\mathrm{kg}$ of $\mathrm{C}^{12}$-D-methionine, a sustained increase of cerebral radioactivity, presumably present mostly as methionine, was noted (Fig. 6), in contrast to the situation arising after the administration of tracer doses of $\mathrm{C}^{14}-\mathrm{D}$ methionine alone (Fig. 2) when the radioactivity rapidly decayed after $1.5 \mathrm{hr}$. Similarly, Fig. 7(a) illustrates the sustained retention of more than $0.5 \%$ of the injected dose in $4 \mathrm{hr}$. Conversely, renal retention did not exceed $1.5 \%$ most probably because the D-amino acid was effectively catabolized in this organ by the highly active $\mathrm{D}$-amino acid oxidase sys- 


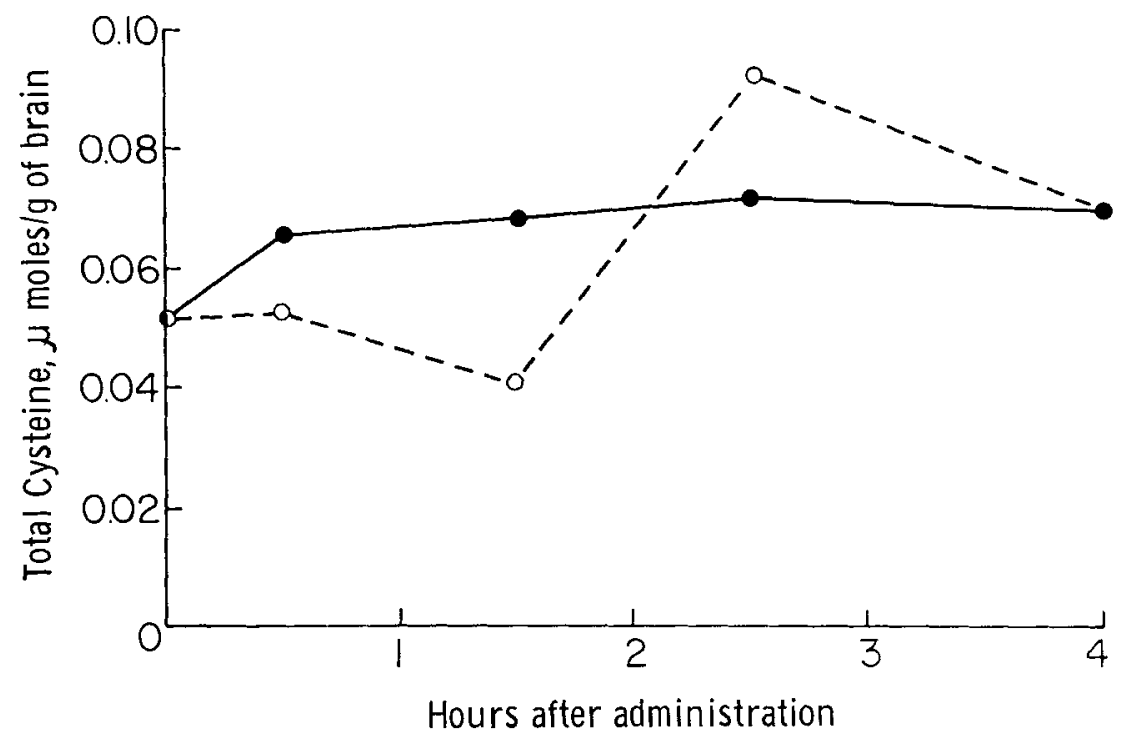

Fig. 4. Total brain cysteine after the administration of a tracer dose of D-methionine. The conditions were as described in the caption for Fig. 1. Cysteine (+ cystine) was determined by the method of Gaitonde (1967). The y-intercept indicates the endogenous concentration of cysteine: $0.052 \mu$ moles/g. (-) D-methionine; (--) Dmethionine $+0.94 \mathrm{mmoles} / \mathrm{kg}$ of $\mathrm{MSO}$.

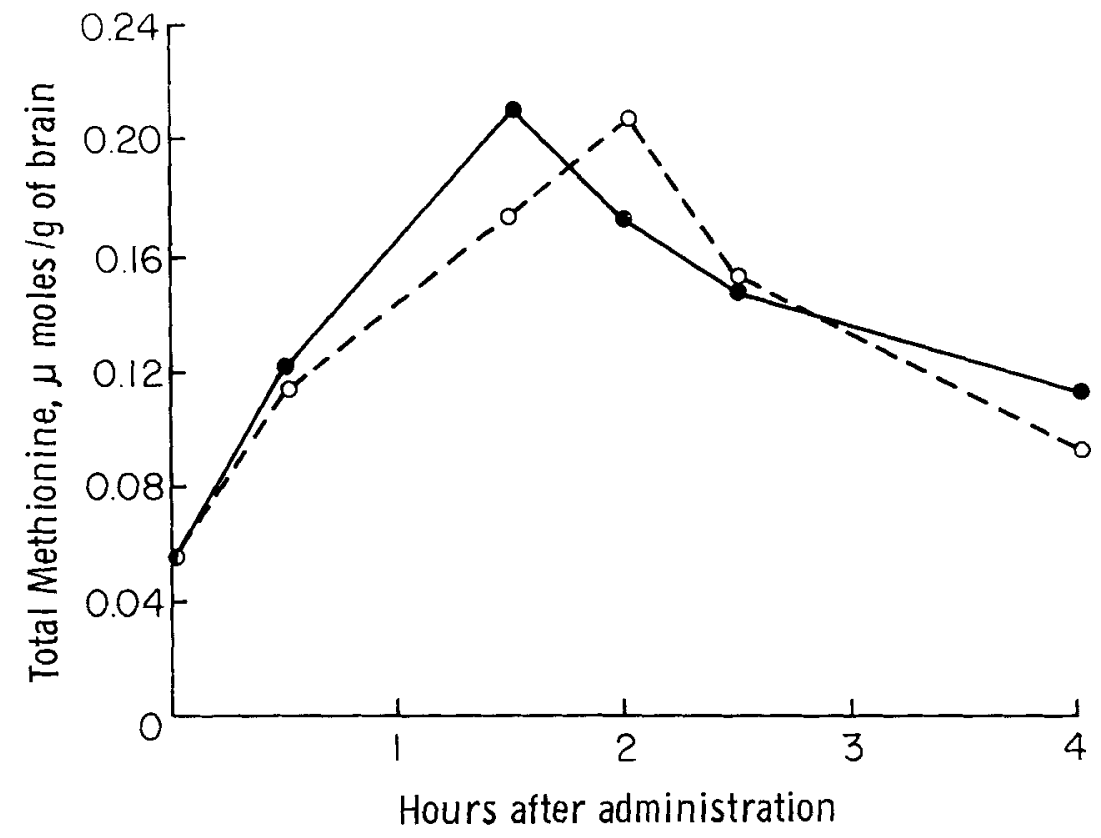

Fig. 5. Total brain methionine after the administration of large dose of D-methionine. $4.7 \mathrm{mmoles} / \mathrm{kg}$ of $\mathrm{D}$-methionine were administered intraperitoneally. Otherwise, all conditions were as described in the caption for Fig. 1. (-) D-methionine + $0.94 \mathrm{mmoles} / \mathrm{kg}$ of MSO. 


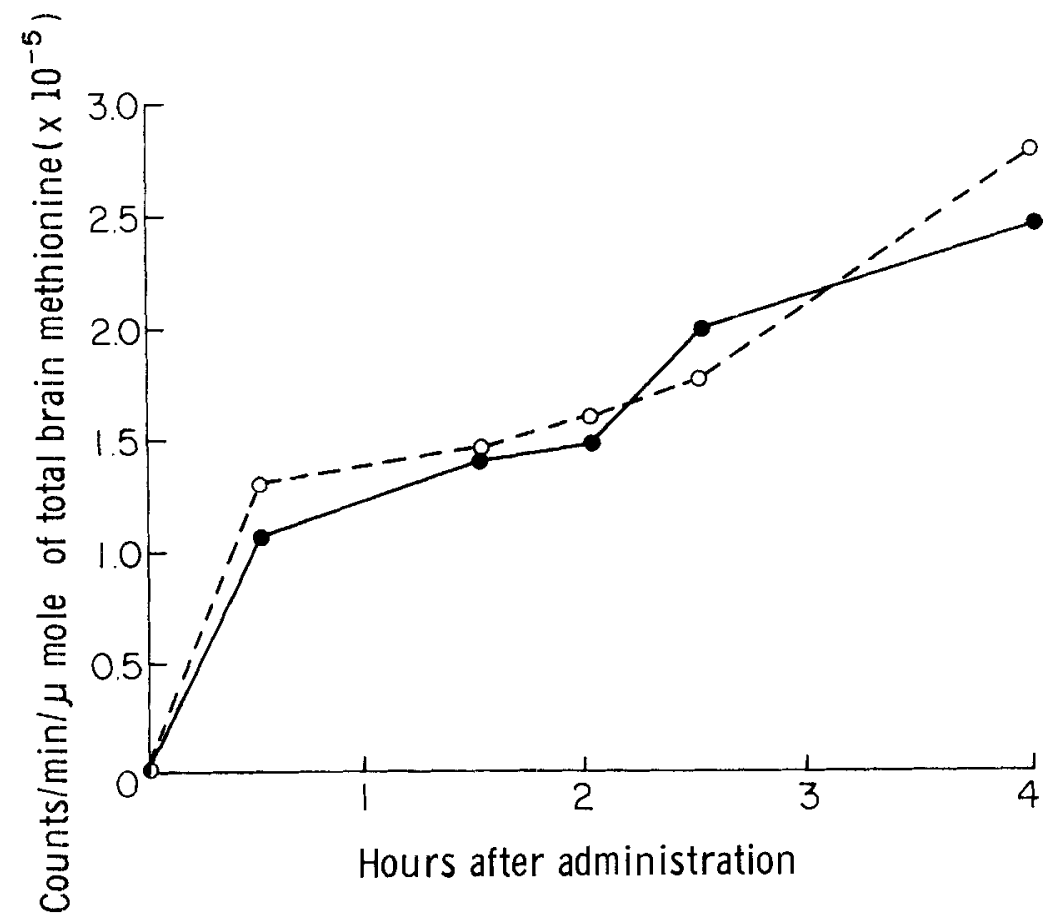

Fig. 6. The time course of cerebral labelling. A large dose $(4.7 \mathrm{mmoles} / \mathrm{kg})$ of $\mathrm{C}^{12}-\mathrm{D}$ methionine which also contained $4.5 \times 10^{6} \mathrm{cpm}$ of $\mathrm{C}^{14}$-D-methionine was injected. See the caption for Figure 2 for details. (--) D-methionine; (..-) D-methionine + 0.94 mmoles $/ \mathrm{kg}$ of MSO.

tem. Cysteine values in the brain peaked at $2.5 \mathrm{hr}$ and then began to return to control levels (Fig. 8).

The effect of MSO on the entry and the accumulation in the brain of the seizure-protective amounts of $\mathrm{D}$-methionine was negligible, as shown by the dashed line of Figs. 6 and 7 . Yet, as shown by the dashed line of Fig. 8, a diminished conversion to cysteine was elicited and could be sustained for about $3 \mathrm{hr}$. As documented below (Table 1), an inhibitory effect of MSO on the conversion of the D-methionine to the L-isomer may be invoked to explain these findings.

Effect of lowering the molar ratio of D-methionine to MSO. Figures 1 and 5 showed that the administration of MSO with low or high $\mathrm{D}$-methionine resulted in an increment of total brain methionine over and above the endogenous value of $0.059 \mu$ moles $/ g$ (Ghittoni and Sellinger, 1970) which was half-maximal at $2.5 \mathrm{hr}$. This effect of MSO is represented in Fig. 1 by $0.092 \mu$ moles /g and in Fig. 5 by $0.145 \mu$ moles $/ \mathrm{g}$ of total brain methionine. Since these changes in total brain methionine were elicited by tracer vs. seizure-protective amounts, it was of interest to examine the effect of intermediate molar ratios of $\mathrm{D}$-methionine to MSO. Figure 9 shows the results of an experiment in which groups of 


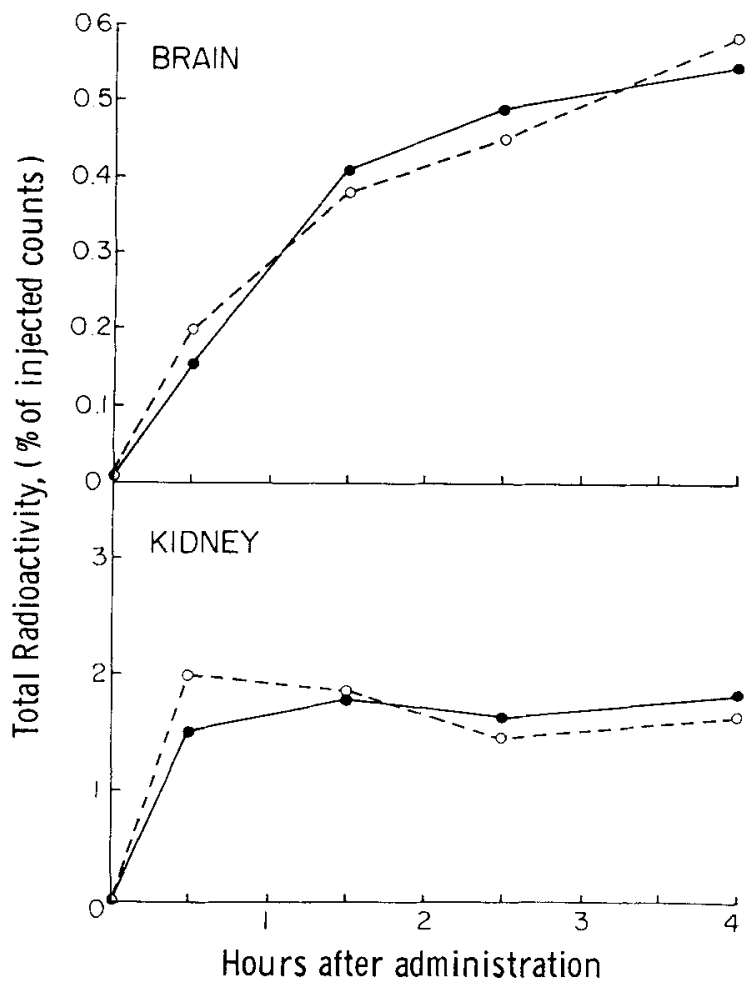

Fig. 7. The total radioactivity of brain and kidney after the administration of a large dose of D-methionine. For details of injection, see the caption for Fig. 6. For other details, see the caption for Fig. 3. (-) D-methionine; (--) D-methionine + $0.94 \mathrm{mmoles} / \mathrm{kg}$ of MSO.

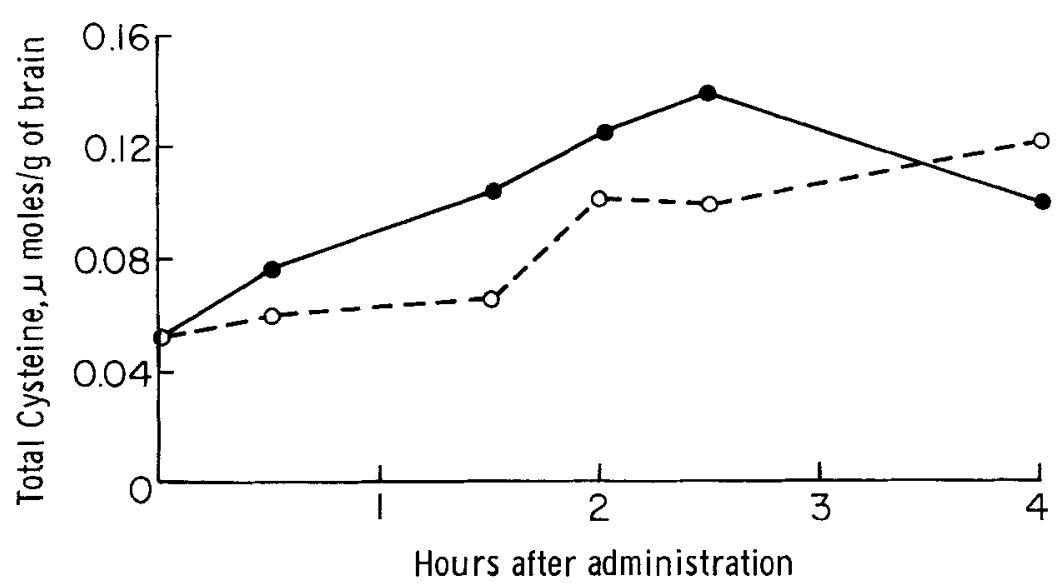

Fig. 8. Total brain cysteine after the administration of a large dose of D-methionine. See the caption for Fig. 6 for details of injection and the caption for Fig. 4 for all other details. (-) D-methionine; (---) D-methionine $+0.94 \mathrm{mmoles} / \mathrm{kg}$ of MSO. 
Table 1

Effect of MSO on the Conversion of D- to L-Methionine*

\begin{tabular}{|c|c|c|c|c|c|c|c|c|}
\hline \multirow{3}{*}{$\begin{array}{l}\text { Methionine } \\
\text { in brain }\end{array}$} & \multicolumn{8}{|c|}{$\begin{array}{l}\text { Time after administration of D-methionine } \pm \text { MSO } \\
1.5 \mathrm{hr}\end{array}$} \\
\hline & \multicolumn{2}{|c|}{ D-methionine } & \multicolumn{2}{|c|}{$\begin{array}{l}\text { D-methionine } \\
\quad+\mathrm{MSO}\end{array}$} & \multicolumn{2}{|c|}{ D-methionine } & \multicolumn{2}{|c|}{$\begin{array}{l}\text { D-methionine } \\
\quad+\text { MSO }\end{array}$} \\
\hline & $\mu$ moles $/ \mathrm{g}$ & $\%$ & $\mu /$ moles & $\%$ & $\mu$ moles $/ \mathrm{g}$ & $\%$ & $\mu$ moles $/ \mathrm{g}$ & $\%$ \\
\hline Total $\dagger$ & 0.192 & 100 & 0.167 & 100 & 0.165 & 100 & 0.173 & 100 \\
\hline D-isomer $\ddagger$ & 0.123 & 64 & 0.118 & 70.6 & 0.077 & 46.5 & 0.109 & 63 \\
\hline L-isomer§ & 0.069 & 36 & 0.049 & 29.4 & 0.088 & 53.5 & 0.064 & 37 \\
\hline $\begin{array}{l}\text { Ratio: D/L } \\
\text { Percent } \\
\text { L-change } \\
\text { due to } \\
\text { MSO }\end{array}$ & 1. & & 2.4 & & 0.87 & & 6.5 & \\
\hline
\end{tabular}

* D-methionine $(4.7 \mathrm{mmoles} / \mathrm{kg})$ was administered alone or simultaneously with $0.94 \mathrm{mmoles} / \mathrm{kg}$ of MSO to groups of rats, one half of which were killed $1.5 \mathrm{hr}$ and the other $2 \mathrm{hr}$ post-injection. Total and D-methionine levels were determined (see Methods).

† Determined analytically by the procedure of Awwad and Adelstein (1966), see Methods.

$\ddagger$ Determined enzymatically by the procedure of Schmitt and Zenk (1968).

$\S$ Calculated by difference between the total and the $\mathrm{D}$-isomer values.

rats were injected with 0.94 mmoles $/ \mathrm{kg}$ of MSO alone or simultaneously with 0.0023 (tracer), $1.15,2.3$, and $4.7 \mathrm{mmoles} / \mathrm{kg}$ of $\mathrm{D}$-methionine and cerebral methionine and cysteine were determined $2.5 \mathrm{hr}$ later. In confirmation of some of our previous results (Ghittoni and Sellinger, 1970), the injection of MSO alone resulted in a fall of cerebral methionine from an endogenous level of $0.059 \mu$ moles $/ g$ to $0.042 \mu$ moles $/ g$ and an elevation of cerebral cysteine from an endogenous level of $0.052 \mu$ moles $/ \mathrm{g}$ to 0.093 $\mu$ moles $/ \mathrm{g}$. However, as expected, the joint administration of MSO + 1.15 or $2.3 \mathrm{mmoles} / \mathrm{kg}$ of D-methionine resulted in maximal levels of total brain methionine of about $0.1 \mu$ moles $/ g$; yet interestingly, the levels of cysteine remained constant at about $0.1 \mu \mathrm{mole} / \mathrm{g}$ irrespective of the molar ratio of D-methionine to MSO.

Brain glutathione. The cerebral levels of glutathione were not affected by the administration of MSO and D-methionine alone or together and its tissue levels, determined in 40 animals under a number of different experimental conditions, average $1.10 \pm 0.12 \mu$ moles $/ \mathrm{g}$ of brain (Kandera et al., 1968; Himwich and Agrawal, 1969).

Conversion of $D$ - to $L$-methionine. In their study of the efflux of amino acids from the mouse brain, Lajtha and Toth (1962) noted "no significant metabolism" of intracerebrally injected D-amino acids and concluded that the $\mathrm{D}$-isomers of leucine, lysine and phenylalanine left the brain unchanged, both as a result of net outflow and of replacement by the natural L-isomers. Subsequently, Lajtha and Toth (1963) suggested 


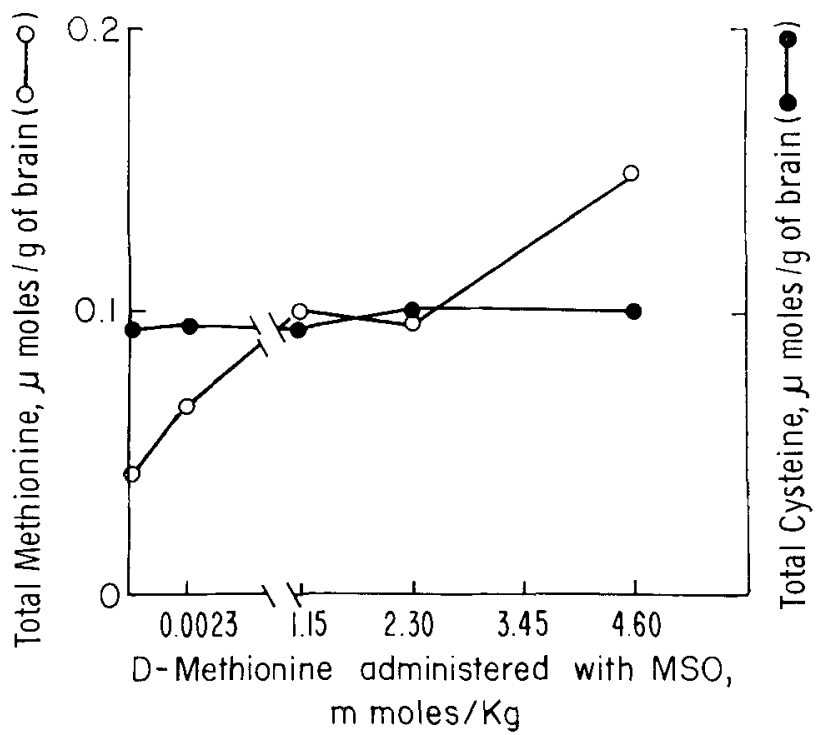

Fig. 9. The effect of lowering the D-methionine-MSO ratio on total brain methionine and cysteine. 0.94 mmoles $/ \mathrm{kg}$ of $\mathrm{MSO}$ were administered simultaneously with $\mathrm{D}$ methionine as indicated, and all the animals were killed $2.5 \mathrm{hr}$ later. The y-intercept represents cerebral levels of methionine (O--O) and cysteine (-.-6) $2.5 \mathrm{hr}$ after the administration of $0.94 \mathrm{mmoles} / \mathrm{kg}$ of MSO alone [taken from Ghittoni and Sellinger 1970)].

that an inefficient "inward transport" was operative for the D-, but not for the L-amino acids.

Since the results of the massive D-methionine administration [Figs. 6 and $7(a)$ ] indicated a steady increase of the radioactivity in the brain and, more specifically, of the radioactivity present as methionine, it became of interest to discriminate between the $\mathrm{D}$ - and the L-methionine isomers and, if possible, determine the proportions of each isomer at selected times after the administration of the unnatural isomer. To this effect, 2 groups of rats were injected with D-methionine and 2 groups with D-methionine and MSO and half of the animals in each group were killed 1.5 and $2 \mathrm{hr}$ later. These particular time points were chosen because of the findings depicted in Fig. 5 which showed total brain methionine to be maximal $1.5 \mathrm{hr}$ after the injection of D-methionine alone and $2 \mathrm{hr}$ after the joint injection of D-methionine and MSO. Thus, the experimental design made it possible to assess the effect of MSO on the D- to L-ratio at times when total brain methionine was either decreasing or increasing.

Table 1 shows that when D-methionine was administered alone, the value of the ratio of $\mathrm{D}$ - to L-methionine fell by more than $100 \%$ in 30 $\mathrm{min}$, i.e., from 1.77 at $1.5 \mathrm{hr}$ to 0.87 at $2 \mathrm{hr}$; whereas, when, MSO was also administered, it decreased by less than $50 \%$, i.e., from 2.40 to 1.70 .

Another indication of the quantitative extent of the conversion of $D$ to L-methionine and of the effect of MSO on this process was obtained 
in the following experiment: 1.5 and $2 \mathrm{hr}$ after the administration of a seizure-protective dose of $\mathrm{C}^{12}$-D-methionine ( + a tracer dose of $\mathrm{C}^{14}-\mathrm{D}$ methionine) alone or jointly with a convulsant dose of MSO, Dowex eluates of brain acid-soluble filtrates (see Methods) were concentrated and chromatographed before and after incubation with L-amino acid oxidase, and the amount of radioactive KMB which was derived exclusively from the $\mathrm{C}^{14}$-L-methionine formed in vivo was determined. The results of this experiment revealed a $14 \%$ increment in the L-isomer after D-methionine alone but a zero increment after D-methionine and MSO, a finding in agreement with the results shown in Table 1 and which provides additional documentation of the block by MSO of the conversion of D- to L-methionine.

\section{DISCUSSION}

The unincumbered ability of L-methionine to penetrate the blood-brain barrier and to exchange with the L-methionine of mammalian brain was first demonstrated by Appel et al. (1960) and later again by Shah et al. (1968). Daniel and Waisman (1969) recently determined a 30-fold increase of methionine in the brain of weanling rats $2 \mathrm{hr}$ after giving 11 mmoles $/ \mathrm{kg}$ of the L-isomer, while Hardwick et al. (1970) noted that the administration of $10 \mathrm{mmoles} / \mathrm{kg}$ of L-methionine to guinea pigs led to profound metabolic alterations and death within $60 \mathrm{hr}$. In the present experiments the maximal injected dose of $4.7 \mathrm{mmoles} / \mathrm{kg}$ of D-methionine elicited no toxic reactions within the short experimental period studied. On the other hand, we are aware of no reports dealing with the in vivo uptake of D-methionine by the brain.

The experiments described in the first part of this report relating to tracer amounts of $\mathrm{C}^{14}$-D-methionine injected alone or with MSO, revealed an early drop of total brain methionine from the endogenous level of 0.059 $\mu$ moles $/ g$ to $0.050 \mu$ moles $/ g$ after the amino acid was given alone and an increase to $0.080 \mu$ moles $/ g$ after MSO was given with it (Fig. 1). In our opinion, it is unlikely that the initial decrement was due to an exchange replacement by the ingoing $D$-isomer of more than equal amounts of outgoing L-methionine; rather, a more likely explanation is that $\mathrm{D}$-methionine was initially rapidly converted to cysteine, via racemization and transsulfuration. Indeed, as shown by the results of Fig. 4, total brain cysteine increased from an endogenous value of $0.052 \mu$ moles $/ \mathrm{g}$ to 0.063 $\mu$ moles $/ \mathrm{g}$ during the first $30 \mathrm{~min}$ post-administration. The increase in total brain methionine noted when MSO was co-administered (Fig. 1, dashed line) did not lead to changes in total brain cysteine; hence it must be concluded that MSO interfered with the conversion of D-methionine to cysteine. Evidence for this conclusion is discussed below. A more likely explanation of the increase is then, in our opinion, a facilitatory effect of MSO on the "inward transport" of D-methionine. We opt for this explanation because of our recent observation of a similar, albeit 
reverse, facilitatory effect of L-methionine on the initial uptake of $\left[\mathrm{H}^{3}\right]$ MSO in three different regions of the rat brain (Ghittoni et al., 1970). Mechanistically, the facilitation may take the form of an MSO-induced increase in affinity of the D-methionine for a specific carrier system, or for the carrier system which mediates the transport of L-methionine and for which D-methionine may also have a high degree of affinity; or, perhaps, it may involve no such change in affinity but a transient acceleration of the flux of the carrier-linked D-methionine into the brain instead.

The dashed line of Fig. 2 suggests that the putative MSO-facilitated "inward transport" brought proportionately more $\mathrm{C}^{12}$ (of unknown isomeric distribution) than $\mathrm{C}^{14}-\mathrm{D}$-methionine into the brain, with the result that the values of counts $/ \mathrm{min} / \mu$ mole of total brain methionine were appreciably lower under these conditions than when $\mathrm{C}^{14}-\mathrm{D}$-methionine was given alone (Fig. 2, solid line). Most likely, a large proportion of the increase in total brain methionine was the result of the "mobilization" of peripheral L-methionine stores which appeared to be able to enter the brain at a high rate for at least $4 \mathrm{hr}$ (Fig. 1). Net efflux of radioactivity from the brain began at about $1.5 \mathrm{hr}$ [Figs. 2 and $3(\mathrm{a})$ ]; and there appeared to be no preferred retention of $\mathrm{C}^{14}$-D-methionine in the brain, since the descending slopes of the curves of Figs. 2 and 3(a) were virtually identical.

An analysis of the "inward transport" of the seizure-protective doses of D-methionine (Sellinger et al., 1968), and of the effects of MSO thereon, reveals no particular features which would aid in the distinction between specific mechanisms governing the "inward transport" of tracer vs. massive doses. Obviously, as a result of the administration of the latter and of the apparently unincumbered passage of D-methionine through the blood-brain barrier, total brain methionine rose by about $400 \%$ above endogenous levels in about $1.5 \mathrm{hr}$. Yet unlike when tracer amounts were given (Fig. 1), it also sharply declined soon thereafter, reaching close to endogenous values in $4 \mathrm{hr}$. A correspondingly high conversion to cysteine appeared to account for at least part of this decline, for the levels of the latter amino acid exceeded the endogenous values by about $300 \%$ in $2.5 \mathrm{hr}$ (Fig. 8). The effect of MSO was to delay the appearance of the total brain methionine peak by $30 \mathrm{~min}$ and to block the overall conversion of D-methionine to cysteine. There appeared to be no facilitation by MSO of the initial "inward transport" of D-methionine into the brain as was supposedly the case when tracer amounts of $D$ methionine were administered (see above). Most likely, facilitation by MSO could not occur due to the immediate saturation of all carrier sites with D-methionine.

As shown previously (Ghittoni and Sellinger, 1970), the i.p. administration of a convulsant dose of MSO results in a transient elevation of Lmethionine in the brain with a peak of about $0.1 \mu$ mole $/ \mathrm{g}$ at $2 \mathrm{hr}$. Subsequently (i.e., as the animal nears the time of seizure) cerebral L-methionine falls to below control values of about $0.04 \mu \mathrm{moles} / \mathrm{g}$. Following the 
administration of MSO + D-methionine (4.7 mmoles $/ \mathrm{kg}$ ) (Fig. 5, dashed line), total brain methionine rose to peak levels of about $350 \%$ above the endogenous levels. However, in order to assess the true effect of MSO on the cerebral uptake of D-methionine, we believe that L-methionine values existing after MSO alone (Ghittoni and Sellinger, 1970) must be subtracted from the total methionine values obtaining after $\mathrm{MSO}+\mathrm{D}$ methionine. We also assume that MSO does not selectively activate any pressumed mechanism governing the movement of D-methionine from the plasma into the peripheral tissues [a reasonable assumption in view of the results shown in Fig. $7(\mathrm{~b})$ ] so as to lead to lower plasma and brain methionine without involving "inward transport" mechanisms. On this basis, it may be calculated that MSO markedly impairs the influx of D-methionine into the brain. Expressed as per cent of the values shown by the full line of Fig. 5, the interference ranged from $56 \%$ at $30 \mathrm{~min}$ to $28 \%$ at $2.5 \mathrm{hr}$. It may be noted that the administration of the convulsant pentylenetetrazole did not inhibit the uptake of L-lysine by mouse brain (Lajtha and Toth, 1965). Sturman et al. (1970) have recently shown a slight retardation of the cerebral uptake of $\mathbf{S}^{35}-\mathrm{L}$ methionine by vitamin $B_{6}$-deficient rats which was accompanied by a pronounced increase of brain cystathionine.

Comparison of the in vivo uptakes of D-methionine by rat brain and of D-leucine, D-phenylalanine and D-lysine by mouse brain (Lajtha and Toth, 1963) reveals that of D-methionine to be the slowest. Thus (as estimated from the data of Fig. 5) $45 \mathrm{~min}$ after the injection of D-methionine, total brain methionine rose by only $9 \mu$ moles $/ 100 \mathrm{~g}$ over the endogenous level, compared to increments of 20 and $90 \mu$ moles $/ \mathrm{g}$, respectively, for phenylalanine and leucine (Lajtha and Toth, 1963).

The alterations of the cerebral levels of L-methionine caused by Dmethionine and MSO are shown in Table 1. The data show a more rapid fall of the D-L ratio in the absence of $\mathrm{MSO}$, yet the numerical value of this ratio was higher after the administration of $\mathrm{MSO}+\mathrm{D}$-methionine. These findings suggest that under the two different conditions the exchange of D-methionine for, and/or its conversion to, the L-isomer is regulated by different time constants. An alternate calculation of the data of Table 1 reveals that while the levels of L-methionine were only $0.01 \mu$ moles $/ \mathrm{g}$ higher than the endogenous levels $1.5 \mathrm{hr}$ after the injection of D-methionine, they exceeded these levels by $0.029 \mu$ moles/g at $2 \mathrm{hr}$. This finding points to the operation of an efficient cerebral mechanism for the exchange of the $\mathrm{D}$-isomer for, or its conversion to, the L-isomer. Conversely, the same calculation reveals that, provided the endogenous values subtracted were those of L-methionine at 1.5 and $2 \mathrm{hr}$ after MSO alone (Ghittoni and Sellinger, 1970), brain L-methionine levels were lower by 0.030 and $0.036 \mu$ moles $/ g$ when MSO was administered than when it was not. Therefore, these results show a net positive effect of the administration of a D-amino acid on the cerebral levels of the corresponding L-isomer and interference with this conversion by a pharmacologically 
active methionine derivative in contrast to the report by Lajtha and Toth (1963) who noted no significant alteration of the cerebral L-leucine in the brain of Swiss mice receiving $\mathrm{D}$-leucine.

\section{REFERENCES}

Appel, K. R., Appel, E., and Maurer, W. (1960). Konzentration und Austauschrate des freien Methionins im Gehirn der Ratte. Biochem. Z. 332: 293-306.

Awwad, H. K. and Adelstein, S. J. (1966). A quantitative method for the determination of the specific radioactivity of sulfur-containing amino acids separated by paper chromatography. Anal. Biochem. 16: 433-437.

Burch, H. B., Lowry, O. H., Padilla, A. M., and Combs, A. M. (1956). Effects of riboflavin deficiency and realimentation on flavin enzymes of tissues. J. Biol. Chem. 223: $29-45$.

Chirigos, M., Greengard, P., and Udenfriend, S. (1960). Uptake of tyrosine by rat brain in vivo. J. Biol. Chem. 235: 2075-2079.

Daniel, R. G. and Waisman, H. A. (1969). The influence of excess methionine on the free amino acids of brain and liver of the weanling rat. J. Neurochem. 16: 787795.

De Marchi, W. J. and Johnston, G. A. R. (1969). The oxidation of glycine by Damino acid oxidase in extracts of mammalian central nervous tissue. J. Neurochem. 16: $355-361$.

de Robertis, E., Sellinger, O. Z., Rodriguez de Lores Arnaiz, G., Alberici, M., and Ziener, L. M. (1967). Nerve endings in methionine sulfoximine convulsant rats: a neurochemical and ultrastructural study. J. Neurochem. 14: 81-89.

GaITONDE, M. K. (1967). A spectrophotometric method for the direct determination of cysteine in the presence of other naturally occurring amino acids. Biochem. J. 104: $627-633$.

Ghittoni, N. R., Ohlsson, W. G., and Sellinger, O. Z. (1970). The effect of methionine on the regional and intracellular disposition of ${ }^{3} \mathrm{H}$-methionine sulfoximine in rat brain. J. Neurochem. 17: 1057-1068.

Ghittoni, N. E. and Sellinger, O. Z. (1970). Cerebral methionine and cysteine levels after the injection of the convulsant methionine sulfoximine. Pharmacol. Res. Comms. 2: 117-120.

Goldstern, D. B. (1966). D-amino acid oxidase in brain: distribution in several species and inhibition by pentobarbitone. J. Neurochem. 13: 1011-1016.

Guroff, G. and Udenfriend, S. (1962). Studies on aromatic amino acid uptake by rat brain in vivo. J. Biol. Chem. 237: 803-806.

Hardwick, D. F., Applegarth, D. A., Cockroft, D. M., Ross, P. M., and Caldeer, R. J., (1970). Pathogenesis of methionine-induced toxicity. Metabolism 19: 381391.

Himwich, W. A. and Agrawal, H. C. (1969). Amino acids. In: Handbook of Neurochemistry, Lajtha, A. (Ed.), Plenum Press, New York, Vol. I, 33-51.

JOCELYN, P. C. (1962). The effect of glutathione on protein sulphydryl groups in rat liver homogenates. Biochem. J. 85: 480-490.

Kandera, J., Levi, G., and Lajtha, A. (1968). Control of cerebral metabolite levels. II. Amino acid uptake and levels in various areas of the rat brain. Arch. Biochem. Biophys. 126: 249-260.

LAJTHA, A. (1968). Transport as control mechanism of cerebral metabolite levels. In: Progress in Brain Research, Lajtha, A. and Ford, D. (Eds.). Elsevier Press, Amsterdam, Vol. 29, 201-218.

LAJTHA, A. and Tотн, J. (1962). The brain barrier system. III. The efflux of intracerebrally administered amino acids from the brain. J. Neurochem. 9: 199-212. 
LAJThA, A. and Toтн, J. (1963). The brain barrier system. V. Stereospecificity of amino acid uptake, exchange and efflux. $J$. Neurochem. 10: 909-920.

LAJThA, A. and Toth, J. (1965). The effects of drugs on uptake and exit of cerebral amino acids. J. Neurochem. 14: 729-738.

Lamar, C., JR., and Selinger, O. Z. (1965). The inhibition in vivo of cerebral glutamine synthetase and glutamine transferase by the convulsant methionine sulfoximine. Biochem. Pharmacol. 14: 489-506.

Lipmann, F. and Tuttle, L. C. (1945). A specific micromethod for the determination of acyl phosphates. J. Biol. Chem. 159: 21-28.

Nakamura, R. (1963). The transport of histidine and methionine in rat brain slices. J. Biochem. (Tokyo) 53: 314-322.

Neims, A. H., Zifverink, W. D., and Smilack, J. D. Distribution of D-amino acid oxidase in bovine and human nervous tissue. $J$. Neurochem. 13: 163-168.

Robins, E., Roberts, N. R., Eydt, K. M., Lowry, O. H., and Smith, D. E. (1956). Microdetermination of $\alpha$-keto acids with special reference to malic, lactic, and glutamic dehydrogenases in brain. J. Biol. Chem. 218: 897-909.

SchmitT, J. H. and ZENk, M. H. (1968). Determination of D-amino acids by stereospecific enzymic acetylation. Anal. Biochem. 23: 433-441.

Sellinger, O. Z., Azcurra, J. M., and Ohlsson, W. G. (1968). Methionine sulfoximine seizures. VIII. The dissociation of the convulsant and glutamine synthetase inbibitory effects. J. Pharmacol. Exptl. Therp. 164: 212-222.

Shay, N. S., Kamano, A., Glisson, S., and Callison, D. (1968). Studies on the uptake of radiolabeled Dopa, 5-HTP and tryptophan in rat tissues in vivo: effect of methionine, tryptophan and some keto acids. Int. J. Neuropharmacol. 7: 73-86.

Sturman, J. A., Cohen, P. A., and Gaull, G. E. (1970). Metabolism on L-35S-methionine in vitamin $\mathrm{B}_{6}$ deficiency: observations on cystathionuria. Biochem. Med. 3: $510-523$.

Yang, S. F., KU, H. S., and Pratt, H. K. (1967). Photochemical production of ethylene from methionine and its analogues in the presence of flavin mononucleotide. J. Biol. Chem. 242: 5274-5280. 